\title{
Epiphytic bryophyte vegetation of Beldibi and Babadağ forests (Zonguldak, Turkey)
}

\author{
Mevlüt ALATAŞ ${ }^{1 *}$ Tülay EZER ${ }^{2}$, Nevzat BATAN ${ }^{3}$ \\ 1*Munzur University, Engineering Faculty, Department of Bioengineering, 62000, Tunceli, Turkey, \\ ${ }^{2}$ Niğde Ömer Halisdemir University, Faculty of Science, Department of Biology, 51100, Niğde, TURKEY, \\ ${ }^{3}$ Karadeniz Technical University, Maçka Vocational School, 61750, Trabzon, TURKEY,
}

Corresponding author: mevlutalatas@hotmail.com

\begin{abstract}
In this study, epiphytic bryophyte vegetation of Beldibi and Babadağ forests has been studied in northwest Turkey (Zonguldak). A total of 55 sample plots were studied. Phytosociological data, obtained from sampe plots, were classified according to the Barun Balnquet method. And also sample plots were ordinated with Detrended Correspondance Analysis (DCA) and classified with two-way indicator species analysis (TWINSPAN). The results indicated that three bryosociological unit were determined from the forests. These; Neckeretum crispae, Anomodonto viticulosi-Leucodontetum sciuroidis and, Orthotricho straminei-Pterigynandretum filiformis. Amanog them Neckeretum crispae was reported for the first time from Turkey.
\end{abstract}

Key Words: Bryophyte, Epiphyte, Vegetation, Zonguldak, Turkey

\section{Introduction}

Bryophytes are a conspicuous and ecologically significant component of mountain forests, and grows on various substrates such as soil, rocks, living and dead trunks, branches. Nevertheless, studies of bryophyte communities from Turkey are lacking, although several studies on bryo-sociology have been carried out with successfully in Turkey as well as bryofloristic studies (Alataş et al. 2017; Alataş and Uyar 2017; Ezer 2017; Can Gözcü et al. 2018; Alataş 2018; Alataş et al. 2019). No study to classify the bryophyte vegetation of the Beldibi and Babadağ forests were made until now. The aim of this study was to reveal the epiphytic bryophyte vegetation of Beldibi and Babadağ forests using DCA and TWINSPAN multivariate analysis techniques as well as Braun-Blanquet method in nortwest Turkey. Neckeretum crispae which was reported for the first time from Turkey with the present paper, brings the total to 47 the number of epiphytic bryophyte syntaxa known from Turkey. Even so, further studies on this topic will be needed to determine and real composition and structure of the Turkish bryophyte vegetation.

\section{Material and Methods}

\section{Study area}

Beldibi and Babadağ forests (Zonguldak, Devrek), located in A2 grid-square according to the Henderson (1961), are located in Euxine zone of Euro-Siberian phytogeographic region (Anşin 1983). The study area, situated in the Western Black Sea Region, is located within the borders of Zonguldak province. There are Karabük district to the east of the study area, Ereğli district to the west, Zonguldak to the north, Bolu and Düzce provinces to the South (Fig. 1). Since the mountains in Zonguldak are 
parallel to the coast, the climate from the coast to the inner part shows significant changes. Depending on these climate changes, different vegetation types such as Oceanic, Mediterranean and SubMediterranean are seen from the north to the south of the area (Güvenç et al. 2009).

The average precipitation is $902 \mathrm{~mm}$ and the average annual temperature is $13.9^{\circ} \mathrm{C}$ in the study area. The hottest month of the year is July and the coldest month is January (URL,1). The annual precipitation regime of the study area is KSII. This situation indicates that the study area has a oceanic climate and it is located in a transitional zone of the sub-mediterranean bioclimatic region (Akman 2011).

The Black Sea Region is particularly suitable for the development of leafy forests. While the conifer Pinus nigra J.F.Arnold subsp. nigra var. pallasiana Schneid is the most dominant species in the study area, the deciduous species Fagus orientalis Lipsky. and Carpinus betulus L. are the co-dominant. And also, Castane sativa Miller., Quercus petraea (Mattuschka) Liebl., Acer platanoides L., Tilia rubra DC., Salix caprea L., Cornus mas L. and, Platanus orientalis L. are other common species in the study area.

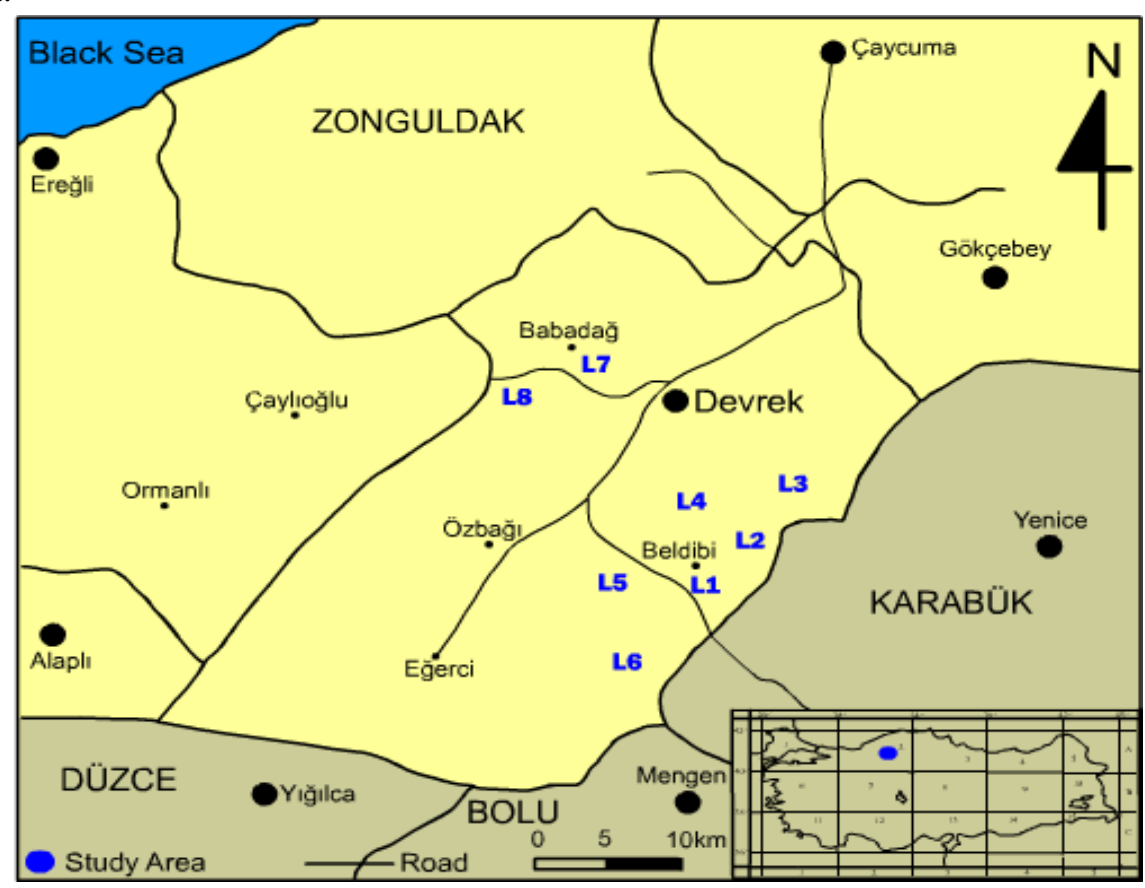

Figure 1. Grid system of Turkey adopted by Henderson (1961) and the study area.

\section{Vegetation sampling}

According to the Braun-Blanquet method (Braun-Blanquet, 1964), a total of 55 phytosociological relevés were taken from the lower $(0-0,5 \mathrm{~m})$ and middle $(0,5-2 \mathrm{~m})$ zones of the trunks of trees which found in the different localities of the Beldibi and Babadağ forests during the different vegetation periods of 2014 (Table 1). The relevés were selected depending on the minimal area concept. For the relevés, abundance-coverage scale of Frey and Kürschner was used (Frey and Kürschner 1991; Table 2).

Phytosociological data, obtained from relevés, were evaluated in accordance with the classical method of Braun-Blanquet (1964). In addition, multivariate analysis techniques such as Two Way Indicator Species Analysis (TWINSPAN; Hill, 1979b) and Detrended Correspondance Analysis (DECORANA; Hill 1979a) were used for classification and ordination respectively. Bryophyte associations were arranged by diagnostic species (Braun-Blanquet 1964) and named according to Weber et al. (2000). 
Table 1. The list of localities.

\begin{tabular}{|c|c|c|c|c|c|}
\hline $\begin{array}{l}\text { Number } \\
\text { of relevés }\end{array}$ & Localities & $\begin{array}{c}\text { Altitude } \\
\text { (m) }\end{array}$ & Phorophyte & Date & GPS Coordinates \\
\hline $1-5$ & 1 & 451 & $Q . p$. & 19.05.2014 & 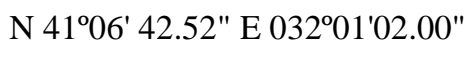 \\
\hline $6-11$ & 2 & 566 & T.r., F.o., C.b. & 19.05 .2014 & 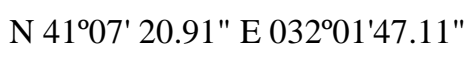 \\
\hline $12-18$ & 3 & 539 & $\begin{array}{c}\text { C.b., A.p., T.r., } \\
\text { F.o., Q.p. }\end{array}$ & 20.05 .2014 & 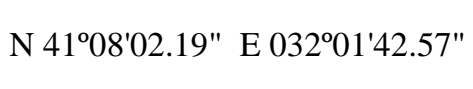 \\
\hline $19-24$ & 4 & 485 & C.b., A.p., F.o. & 26.06 .2014 & N 41이'54.02" E 032º1'16.86" \\
\hline $25-36$ & 5 & 357 & P.o. & 27.06 .2014 & N 4107'27.87" E 031'59'42.49" \\
\hline $37-45$ & 6 & 495 & $\begin{array}{c}\text { C.m., S.c., } \\
\text { Q.p., C.b., F.o. }\end{array}$ & 28.06 .2014 & N 4106'25.06" E 03159'09.62" \\
\hline $46-51$ & 7 & 583 & Q.p., C.b., F.o. & 12.09.2014 & 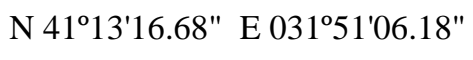 \\
\hline $52-57$ & 8 & 669 & Q.p., C.b. & 13.09 .2014 & N 41 ${ }^{\circ} 12^{\prime} 48.86^{\prime \prime}$ E 031 $50^{\circ} 10.82^{\prime \prime}$ \\
\hline
\end{tabular}

F.o.; Fagus orientalis, C.b.; Carpinus betulus, T.r.; Tilia rubra, Q.p.: Quercus petraea, A.p.: Acer platanoides, S.c.: Salix caprea, C.m.: Cornus mas, P.o.: Platanus orientalis

Table 2. Abundance-coverage scale used for bryophytes.

\begin{tabular}{lllc}
\hline scale & Abundance-coverage & scale & Abundance-coverage \\
\hline+ & $<\% 1$ & 3 & $\% 12,1-25,0$ \\
1 & $\% 1,1-6,0$ & 4 & $\% 25,1-50,0$ \\
2 & $\% 6,1-12,0$ & 5 & $\% 50,1-100$ \\
\hline
\end{tabular}

The determination of the associations in the present study was carried out via comparison with related associations in Marstaller (2006) and classified with the aid of published studies. For the identification of the epiphytic bryophyte specimens, different floras, monographies and revisions were used (Nyholm 1981; Hedenäs 1992; Smith 2004; Zander 1993; Paton 1999; Cortini Pedrotti 2001, 2006; Heyn and Herrnstadt 2004; Frey et al. 2006; Guerra and Cros 2007; Casas et al. 2009; Kürschner and Frey 2011, Plášek et al. 2015; Lara et al. 2016).

\section{Results and Discussion}

\section{Classification of Braun-Blanquet method}

As a results of phytosociological data obtained from total 55 relevés, three epiphytic bryophyte associations were determined using Braun-Blanquet (1964) method. These; Neckeretum crispae (Kaiser 1926) Herzog et Höffler 1944, Anomodonto viticulosi-Leucodontetum sciuroidis Wisn. 1930 and, Orthotricho straminei-Pterigynandretum filiformis Gillet 1986. The Neckeretum crispae was reported for the first time from Turkey.

Floristic and ecological features of these syntaxa are given below in accordance with Marstaller's (2006) sequence.

Class: Neckeretea complanatae Marst. 1986

Order: Neckeretalia complanatae Jez. and Vondr. 1962

Alliance: Neckerion compalanatae Sm. and Had. ex Kl. 1948

Associations: Anomodonto viticulosi-Leucodontetum sciuroidis Wisn. 1930

Neckeretum crispae (Kaiser 1926) Herzog et Höffler 1944

Class: Frullanio dilatatae-Leucodontetea sciuroidis Mohan 1978

Order: Orthotrichetalia Had. in Kl. and Had. 1944

Alliance: Ulotion crispae Barkm. 1958

Association: Orthotricho straminei-Pterigynandretum filiformis Gillet 1986 


\section{Description of the syntaxa}

Anomodonto viticulosi-Leucodontetum sciuroidis Wisn. 1930 (Table 3)

The association was first described by Wisniewski in Poland and later recorded in Eastern Germany, Estonia, Sweden and the Netherlands respectively (Barkman 1958). Later, it was recorded by Goia and Schumacker (2004) in Romania. The association which is also the type association of the Anomodonto-Leucodontenion sciuroidis suballiance, wide-spreads on tree trunks in of shade, alkaline and very humid areas (Barkman 1958; Marstaller 2006).

The association occurs exclusively in the eastern and southern parts of the study area. It was determined within the total of 10 sample plots between 357-539 meters. The sample plots are situated on tree trunks that are spread on moist and shaded habitats in the eastern and southern parts of the study area. The association is similar to the European association in terms of ecological characteristics. It spreads on deciduous tree trunks in European localities such as Carpinus betulus, Tilia ulmifolia, T. cordata, Fraxinus excelsior, Ulmus montana, Salix caprea, Acer platonoides, Fagus sylvatica, Quercus robur and, Alnus glutinosa (Barkman 1958). Similarly, it occurs on Fagus orientalis, Platanus orientalis, Cornus mas, Tilia rubra and, Quercus petraea trunks in the study area (Fig. 2).

Table 3. Anomodonto viticulosi-Leucodontetum sciuroidis Wisn. 1930.

\begin{tabular}{|c|c|c|c|c|c|c|c|c|c|c|}
\hline Number of relevés & 37 & 38 & 33 & 34 & 36 & 17 & 40 & 41 & 18 & 31 \\
\hline Altitude (m) & 495 & 495 & 357 & 357 & 357 & 539 & 495 & 495 & 539 & 357 \\
\hline Size of relevés $(\mathrm{dm} 2)$ & 9 & 4 & 12 & 12 & 16 & 12 & 6 & 9 & 8 & 16 \\
\hline Phorophyte & C.m. & C.m. & P.o. & P.o. & P.o. & T.r. & Q.p. & Q.p. & F.o. & P.o. \\
\hline Trunk (m) & 1,2 & 1,1 & 1,7 & 7,7 & 5,5 & 1,5 & 0,8 & 0,9 & 2 & 1,5 \\
\hline Exposition & $\mathrm{K}$ & $\mathrm{K}$ & $\mathrm{K}$ & $\mathrm{K}$ & $\mathrm{K}$ & $\mathrm{K}$ & $\mathrm{KB}$ & $\mathrm{KB}$ & $\mathrm{K}$ & $\mathrm{K}$ \\
\hline Position of relevés & $\mathrm{K}$ & $\mathrm{K}$ & $\mathrm{K}$ & K & $\mathrm{K}$ & $\mathrm{K}$ & $\mathrm{K}$ & $\mathrm{K}$ & $\mathrm{K}$ & $\mathrm{K}$ \\
\hline Covering (\%) & 88 & 95 & 90 & 98 & 92 & 93 & 90 & 95 & 91 & 90 \\
\hline Closure (\%) & 80 & 80 & 70 & 70 & 70 & 90 & 80 & 80 & 90 & 70 \\
\hline Base (B) / Trunk (T) & B & B & $\mathrm{T}$ & $\mathrm{T}$ & B & $\mathrm{T}$ & B & B & B & $\mathrm{T}$ \\
\hline Number of species & 7 & 5 & 6 & 6 & 7 & 7 & 6 & 7 & 9 & 5 \\
\hline \multicolumn{11}{|l|}{ Characteristic species } \\
\hline Anomodon viticulosus (Hedw.) Hook. \& Taylor. & 2 & 3 & 1 & 3 & 3 & 2 & 2 & 2 & & \\
\hline Leucodon sciuroides (Hedw.) Schwägr. & 3 & 2 & 3 & 3 & 3 & 3 & 4 & 4 & 2 & 4 \\
\hline \multicolumn{11}{|c|}{ Characteristic species of the Neckerion complanatae alliance } \\
\hline $\begin{array}{l}\text { Alleniella besseri (Lobarz.) S.Olsson, Enroth } \\
\text { \& D.Quandt. }\end{array}$ & 2 & & & & & & & & & \\
\hline Homalia trichomanoides (Hedw.) Brid. & & & & & & & & & 1 & \\
\hline Anomodon attenuatus (Hedw.) Huebener. & & & & & & & & & 1 & \\
\hline \multicolumn{11}{|c|}{ Characteristic species of the Neckeratalia complanatae order and Neckeretea complanatae class } \\
\hline $\begin{array}{l}\text { Alleniella complanata (Hedw.) S.Olsson, Enroth \& } \\
\text { D.Quandt. }\end{array}$ & 4 & 4 & 2 & & 2 & 4 & & 2 & 4 & 3 \\
\hline Homalothecium sericeum (Hedw.) Schimp. & 2 & 3 & 4 & 4 & 4 & 2 & 3 & 3 & 1 & 3 \\
\hline Porella platyphylla (L.) Pfeiff. & 2 & 2 & & & & & & & & \\
\hline Radula complanata (L.) Dumort. & 1 & & & 1 & & 1 & & & 2 & \\
\hline $\begin{array}{l}\text { Hypnum cupressiforme var.cupressiforme Hedw. } \\
\text { Isothecium alopecuroides (Lam. ex Dubois) Isov. }\end{array}$ & & & 2 & 2 & & & 2 & 2 & 1 & 2 \\
\hline \multicolumn{11}{|l|}{ Others } \\
\hline Frullania tamarisci (L.) Dumort. & & & & & & 2 & 3 & & 2 & \\
\hline $\begin{array}{l}\text { Ptychostomum moravicum (Podp.) Ros \& } \\
\text { Mazimpaka. } \\
\text { Pulvigera lyellii (Hook. \& Taylor) } \\
\text { Plášek, Sawicki \& Ochyra. }\end{array}$ & & & & 1 & & & 2 & & & \\
\hline Frullania dilatata (L.) Dumort. & & & 1 & & 1 & & & 1 & & \\
\hline Hypnum resupinatum (Taylor) Schimp. & & & & & 2 & & & & & \\
\hline Zygodon rupestris Schimp. ex Lorentz. & & & & & & & & & & 1 \\
\hline
\end{tabular}




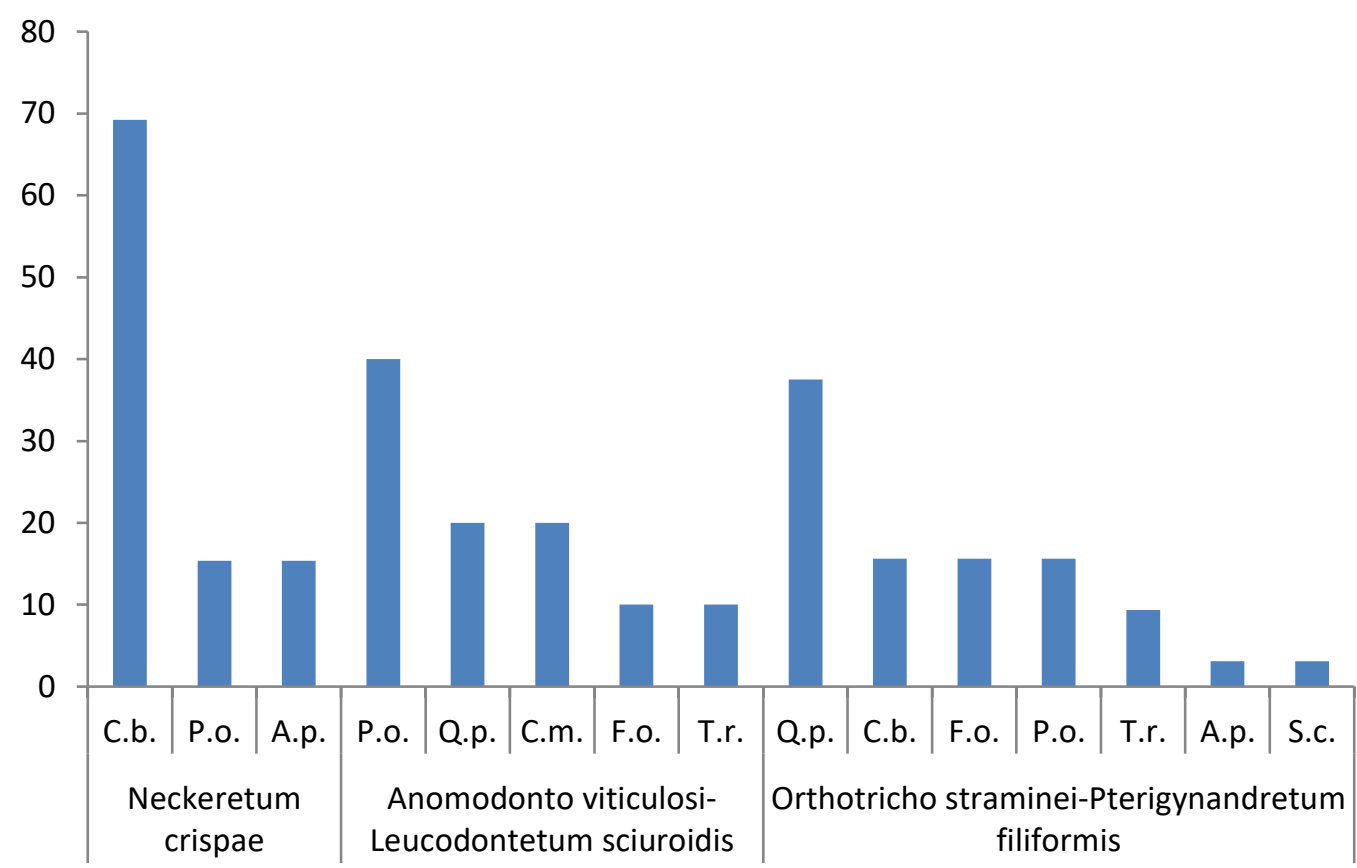

Figure 2. The tree preferences of the syntaxa.

While the general cover of the epiphytic bryophyte species within the association ranges from $88 \%$ to $98 \%$, canopy cover is $70 \%-90 \%$. A total of 17 taxa were recorded in sample plots. 4 of them are liverworts, 13 of them are mosses ( 3 acrocarpous, 10 pleurocarpous). An average number of taxa are 6 within the association. The high proportions of pleurocarpous species, more sensitive to drought than acrocarpous, suggests that the association is generally spread in moist habitats in the study area.

The permanency of Anomodon viticulosus, one of the diagnostic species of the association, is $80 \%$ in the sample plots. The permanency of another diagnostic species Leucodon sciuroides is $100 \%$. The mesophyte taxon Anomodon viticulosus generally grows on trunks as epiphytically and, on stone, wall and, rock as epilithically in shady semi-arid and semi-neutral environments. The mesophyte-xerophyte taxon Leucodon sciuroides, generally grows as epiphytically and epilithically, spreads on acidic and semi-neutral habitats in open areas. Therefore, it can be said that both diagnostic species are strongly compatible with the characteristics of the upper syntaxonomic units (class, ordo, alliance).

This association is characterized by facultative epiphytes with large proportion $(41 \%)$. The percentage of obligate epiphytes is $35 \%$ in the association. Indifferent species were represented by low percentage (24\%) respectively (Fig. 3). In this situation, it can be say that the determined syntaxon in the study area is facultative epiphyte. 


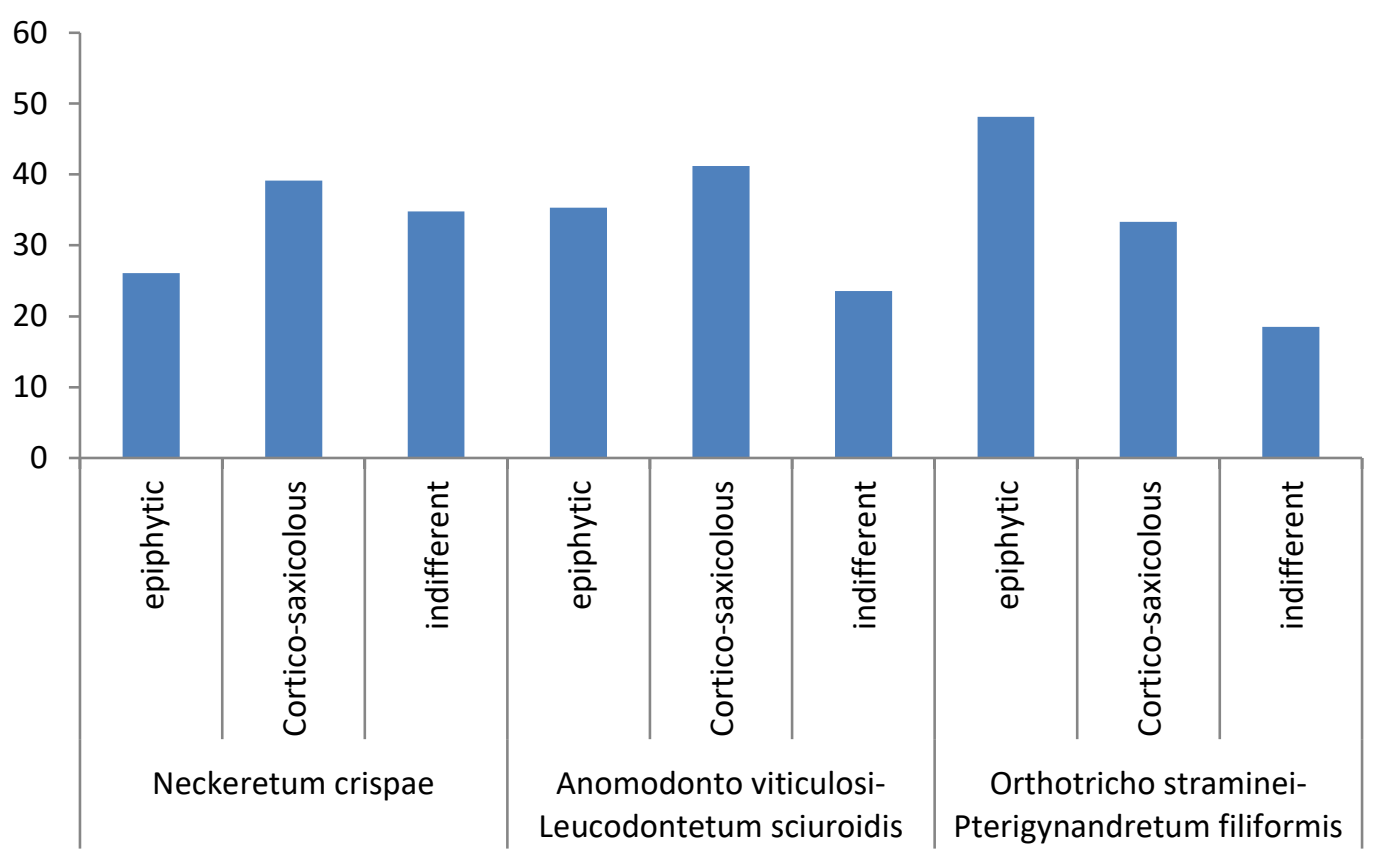

Figure 3. The habitat affinities spectrum of the species of syntaxa.

Syntaxonomically, Anomodonto viticulosi-Leucodontetum sciuroidis Wisn. 1930 was classified in the alliance Neckerion complanatae Sm. \& Had. ex Kl. 1948, the ordo Neckeretalia complanatae Jez. \& Vondr. 1962 and, the class Neckereta complanatae Marst. 1986 due to it includes of characteristic species of the upper units (Table 3 ).

The association, determined in the study area, show some floristic and ecologic similarity to Romanian association previously determined by Goia and Schumacker (2004). Leucodon sciuroides, Porella platyphylla and, Homalothecium sericeum are characteristic species of both associations.

Neckeretum crispae (Kaiser 1926) Herzog et Höffler 1944 (Table 4)

The association was determined with a total 13 sample plots between 357 to 539 meters of the study area. The association occurs mainly northern parts of the lower base and middle zone of trees. The trees are widespread in shade and open areas in the mesic southern and eastern slopes of the study area. Carpinus betulus is the most preferred tree species by the association in the study area (Fig. 2).

While the general bryophyte cover within the association ranges from $85 \%$ to $97 \%$, canopy cover is $70 \%$ $100 \%$. A total of 23 taxa were recorded in the sample plots belonging to the association. Among them, 7 are liverworts and, 16 are mosses ( 3 acrocarpous, 13 pleurocarpous). The average taxa numbers are 7 within the association.

This association highly occurs on deciduous Carpinus betulus, Acer platanoides and Platanus orientalis mixed forests as epiphytically in moist slopes of the study area. At the same time, Exsertotheca crispa, the main diagnostic species of the association, is hygrophytic pleurocarpous taxon. Therefore, it can be said that the association is hygrophytic. The permanency of the main diagnostic species within the sample plots is $85 \%$.

The percentage of cortico-saxicolous members in the association is 39\%. On the other hand, the percentage of epiphytic members is $26 \%$. Indifferent species were represented by highly proportion with $35 \%$ within the association (Fig. 3). Therefore, the association determined in the study area is facultative epiphyte. 
Table 4. Neckeretum crispae (Kaiser 1926) Herzog et Höffler 1944.

\begin{tabular}{|c|c|c|c|c|c|c|c|c|c|c|c|c|c|}
\hline Number of relevés & 11 & 20 & 25 & 12 & 13 & 14 & 21 & 22 & 23 & 24 & 26 & 45 & 42 \\
\hline Altitude (m) & 566 & 485 & 357 & 539 & 539 & 539 & 485 & 485 & 485 & 485 & 357 & 495 & 495 \\
\hline Size of relevés (dm2) & 12 & 9 & 16 & 12 & 9 & 12 & 16 & 16 & 12 & 9 & 12 & 16 & 6 \\
\hline Phorophyte & C.b. & A.p. & P.o. & C.b. & A.p. & C.b. & C.b. & C.b. & C.b. & C.b. & P.o. & C.b. & C.b. \\
\hline Trunk (m) & 1,5 & 1,2 & 2,7 & 1,4 & 1,2 & 1,8 & 1,5 & 1,8 & 1,4 & 1,8 & 4,2 & 2,4 & 1,1 \\
\hline Exposition & $\mathrm{K}$ & $\mathrm{K}$ & K & $\mathrm{K}$ & K & $\mathrm{K}$ & $\mathrm{K}$ & $\mathrm{K}$ & $\mathrm{K}$ & $\mathrm{K}$ & $\mathrm{K}$ & $\mathrm{KB}$ & $\mathrm{KB}$ \\
\hline Position of relevés & $\mathrm{K}$ & $\mathrm{K}$ & K & $\mathrm{K}$ & K & $\mathrm{K}$ & $\mathrm{K}$ & $\mathrm{K}$ & $\mathrm{K}$ & $\mathrm{K}$ & $\mathrm{KD}$ & $\mathrm{K}$ & K \\
\hline Covering (\%) & 94 & 90 & 86 & 85 & 95 & 91 & 92 & 91 & 90 & 97 & 96 & 88 & 90 \\
\hline Closure (\%) & 100 & 80 & 70 & 90 & 90 & 90 & 80 & 80 & 80 & 80 & 70 & 80 & 80 \\
\hline Base (B) / Trunk (T) & $\mathrm{T}$ & B & $\mathrm{T}$ & $\mathrm{T}$ & $\mathrm{T}$ & $\mathrm{T}$ & $\mathrm{T}$ & $\mathrm{T}$ & $\mathrm{T}$ & $\mathrm{T}$ & $\mathrm{T}$ & $\mathrm{T}$ & $B$ \\
\hline Number of species & 7 & 7 & 9 & 8 & 8 & 5 & 7 & 8 & 10 & 7 & 7 & 8 & 7 \\
\hline \multicolumn{14}{|l|}{ Characteristic species } \\
\hline $\begin{array}{l}\text { Exsertotheca crispa (Hedw.) S.Olsson, Enroth \& } \\
\text { D.Quandt }\end{array}$ & 5 & 4 & 2 & 4 & 4 & 5 & 4 & 4 & 4 & 3 & 3 & & \\
\hline \multicolumn{14}{|c|}{ Characteristic species of the Neckerion complanatae alliance } \\
\hline Anomodon viticulosus (Hedw.) Hook. \& Taylor. & & & & & 2 & & & & & & & & \\
\hline Anomodon attenuatus (Hedw.) Huebener. & & & & & & & & & & & & 2 & \\
\hline \multicolumn{14}{|c|}{ Characteristic species of the Neckeratalia complanatae order and Neckeretea complanatae class } \\
\hline $\begin{array}{l}\text { Alleniella complanata (Hedw.) S.Olsson, Enroth \& } \\
\text { D.Quandt. }\end{array}$ & 1 & 2 & 3 & & & & 2 & & 2 & 4 & 4 & 4 & 3 \\
\hline Homalothecium sericeum (Hedw.)Schimp. & 1 & & 3 & & 2 & 2 & 3 & 2 & 2 & & 4 & 2 & 3 \\
\hline Metzgeria furcata (L.) Dumort. & 1 & & & & & & 1 & & & & 1 & & \\
\hline Radula complanata (L.) Dumort. & & 1 & 1 & 2 & 1 & 1 & 2 & 1 & & & 1 & 2 & 1 \\
\hline Isothecium alopecuroides (Lam. ex Dubois) Isov. & & & & 1 & 1 & 3 & & 1 & 1 & 1 & & 1 & 1 \\
\hline Hypnum cupressiforme var.cupressiforme Hedw. & & 2 & 1 & 2 & 2 & & & 2 & 1 & 2 & 2 & 2 & 2 \\
\hline Cirriphyllum crassinervium (Taylor) Loeske \& M.Fleisch. & & & 2 & & & & & & & & & & \\
\hline Porella arboris-vitae (With.) Grolle. & & & & & & & & & 2 & 3 & 1 & & \\
\hline Lejeunea cavifolia (Ehrh.) Lindb. & & & & 1 & 1 & & 2 & 1 & 1 & & & 1 & \\
\hline \multicolumn{14}{|l|}{ Others } \\
\hline Plagiomnium affine (Blandow ex Funck) T.J.Kop. & & & & 2 & 2 & 1 & & 3 & & & & & \\
\hline Leucodon sciuroides (Hedw.)Schwägr. & 3 & 2 & 2 & & & & & & & & & & \\
\hline Pterigynandrum filiforme Hedw. & & 2 & & & & & 2 & & & 2 & & & \\
\hline Frullania tamarisci (L.) Dumort. & 3 & & & 1 & & & & 1 & 1 & 1 & & 2 & \\
\hline Isothecium myosuroides Brid. & 1 & & & & & & & & & & & & \\
\hline Lophocolea heterophylla (Schrad.) Dumort. & & & & 1 & & & & & & & & & \\
\hline Bryum capillare Hedw. & & & & & & & & & 1 & & & & \\
\hline Brachythecium mildeanum (Schimp.) Schimp. & & & 2 & & & & & & & & & & \\
\hline Ptychostomum moravicum (Podp.) Ros \& Mazimpaka. & & & 1 & & & & & & & & & & \\
\hline Frullania dilatata (L.) Dumort. & & & & & & & & & & & & & 1 \\
\hline Antitrichia curtipendula (Hedw.) Brid. & & & & & & & & & & & & & 4 \\
\hline
\end{tabular}

The diagnostic species of the association are Neckera complanata, Metzgeria furcata and Homalothecium sericeum. These species which are diagnostic species of Neckeretalia complanatae are represented by high proportion in the syntaxon. Moreover, Exsertotheca crispa, grows on epiphytic and epilithic habitats, is the main diagnostic species of the facultative epiphyte association. It was therefore supported that the association is classified within the alliance Neckerion complanatae, the ordo Neckeretalia complanatae and the facultative epiphyte class Neckereta complanatae as syntaxonomically (Table 4).

The association, recorded for the first time from Turkey with the present paper, show floristic and ecologic similarity to Italian association previously determined by Cortini Pedrotti (1988) in the 
Quercus ilex forests. Neckera complanata, Metzgeria furcata and Homalothecium sericeum are characteristic species of both associations and of the upper syntaxonomic units to which they are attached.

\section{Orthotricho straminei-Pterigynandretum filiformis Gillet 1986 (Table 5)}

The association is situated in a total of 32 sample plots on the north face of middle and basal parts of trunks of deciduous tree species which are spread on all localities within an elevation range of 357-669 meters in the study area.

The association was firstly described by Ochsner in 1928 with the name of Ulotetum crispae. Along with the changes in the syntaxonomical nomenclature, it was re-edited by Gillet under the name of Orthotricho straminei-Pterigynandretum filiformis Gillet 1986 and introduced to the world of science (Marstaller 2006).

The general bryophyte cover of the association ranges from $82 \%$ to $98 \%$. The canopy cover of the forest where Quercus petraea is the most dominant tree species is $70 \%-100 \%$. At the same time, Quercus petraea is the most preferred phorophyte species by the association with $38 \%$ (Fig. 2). The total number of species in this syntaxon was twenty seven. Among them, six are liverworts and the others are mosses (10 acrocarpous, 11 pleurocarpous). An average number of 7 species was recorded in the sample plots.

The main diagnostic species of association was aero-hygrophyte-mesophyte Orthotrichum stramineum. Although the permanency of the species is $41 \%$, its cover within the association is very low. The permanency of strong competitive species Pterigynandrum filiforme, another diagnostic species of the association, is $75 \%$ and its cover is relatively higher. 
Table 5. Orthotricho straminei-Pterigynandretum filiformis Gillet 1986.

\begin{tabular}{|c|c|c|c|c|c|c|c|c|c|c|c|c|c|c|c|c|c|c|c|c|c|c|c|c|c|c|c|c|c|c|c|c|}
\hline Number of relevés & 1 & 3 & 6 & 7 & 46 & 47 & 48 & 53 & 54 & 55 & 57 & 4 & 8 & 10 & 49 & 50 & 52 & 51 & 2 & 44 & 19 & 32 & 39 & 56 & 43 & 9 & 16 & 29 & 35 & 5 & 27 & 30 \\
\hline Altitude $(\mathrm{m})$ & 451 & 451 & 566 & 566 & 583 & 583 & 583 & 669 & 669 & 669 & 669 & 451 & 566 & 566 & 583 & 583 & 669 & 583 & 451 & 495 & 485 & 357 & 495 & 669 & 495 & 566 & 539 & 357 & 357 & 451 & 357 & 357 \\
\hline Size of relevés $(\mathrm{dm} 2)$ & 12 & 9 & 8 & 12 & 6 & 8 & 4 & 8 & 9 & 8 & 12 & 12 & 6 & 9 & 6 & 9 & 6 & 8 & 9 & 12 & 12 & 9 & 8 & 12 & 6 & 20 & 6 & 12 & 8 & 9 & 20 & 8 \\
\hline Phorophyte & Q.p. & Q.p. & T.r. & T.r. & Q.p. & Q.p. & Q.p. & Q.p. & Q.p. & C.b. & C.b. & Q.p. & T.r. & F.o. & Q.p. & C.b. & Q.p. & F.o. & Q.p. & C.b. & F.o. & P.o. & S.c. & C.b. & F.o. & F.o. & A.p. & P.o. & P.o. & Q.p. & P.o. & P.o. \\
\hline Trunk (m) & 0.8 & 1,1 & 1,2 & 1,2 & 0,9 & 0,8 & 0,7 & 0,8 & 0,9 & 1,5 & 1,6 & 1 & 1 & 1,8 & 1,1 & 1,2 & 0,9 & 1,7 & 0,9 & 1,4 & 1,9 & 3,6 & 1,6 & 1,8 & 1,5 & 2,7 & 0,7 & 1,8 & 2,4 & 1,2 & 2,1 & 1,4 \\
\hline Exposition & K & K & $\mathrm{K}$ & $\mathrm{K}$ & $\mathrm{K}$ & K & $\mathrm{K}$ & $\mathrm{K}$ & $\mathrm{K}$ & $\mathrm{K}$ & K & $\mathrm{K}$ & K & $\mathrm{K}$ & K & $\mathrm{K}$ & K & K & K & KB & $\mathrm{K}$ & K & K & K & $\mathrm{KB}$ & $\mathrm{K}$ & K & K & $\mathrm{K}$ & K & K & K \\
\hline Position of relevés & $\mathrm{K}$ & $\mathrm{K}$ & $\mathrm{K}$ & $\mathrm{K}$ & $\mathrm{K}$ & $\mathrm{K}$ & $\mathrm{K}$ & $\mathrm{K}$ & $\mathrm{K}$ & $\mathrm{K}$ & $\mathrm{K}$ & $\mathrm{K}$ & $\mathrm{K}$ & $\mathrm{K}$ & $\mathrm{K}$ & $\mathrm{K}$ & $\mathrm{K}$ & $\mathrm{K}$ & $\mathrm{K}$ & $\mathrm{K}$ & $\mathrm{K}$ & $\mathrm{K}$ & $\mathrm{K}$ & $\mathrm{K}$ & $\mathrm{K}$ & $\mathrm{K}$ & $\mathrm{K}$ & $\mathrm{K}$ & $\mathrm{K}$ & $\mathrm{KD}$ & KD & $\mathrm{KD}$ \\
\hline Covering (\%) & 90 & 90 & 93 & 82 & 91 & 98 & 85 & 91 & 93 & 95 & 96 & 93 & 80 & 83 & 95 & 86 & 93 & 84 & 95 & 98 & 98 & 93 & 96 & 91 & 98 & 90 & 90 & 95 & 97 & 96 & 88 & 88 \\
\hline Closure (\%) & 90 & 90 & 100 & 100 & 90 & 90 & 90 & 90 & 90 & 90 & 90 & 90 & 100 & 100 & 90 & 90 & 90 & 90 & 90 & 80 & 80 & 70 & 80 & 90 & 80 & 100 & 90 & 70 & 70 & 90 & 70 & 70 \\
\hline Base (B) / Trunk (T) & $\mathrm{T}$ & B & B & $\mathrm{T}$ & $\mathrm{T}$ & B & B & $B$ & B & $\mathrm{T}$ & $\mathrm{T}$ & $T$ & B & $\mathrm{T}$ & B & B & $\mathrm{T}$ & B & $\mathrm{T}$ & $\mathrm{T}$ & B & $\mathrm{T}$ & $\mathrm{T}$ & $\mathrm{T}$ & $\mathrm{T}$ & B & B & $\mathrm{T}$ & $\mathrm{T}$ & $\mathrm{T}$ & $\mathrm{T}$ & $\mathrm{T}$ \\
\hline Number of species & 8 & 7 & 7 & 7 & 10 & 8 & 7 & 7 & 10 & 7 & 9 & 7 & 5 & 5 & 7 & 7 & 6 & 7 & 7 & 9 & 5 & 6 & 10 & 8 & 10 & 6 & 6 & 6 & 6 & 5 & 5 & 6 \\
\hline \multicolumn{33}{|l|}{ Characteristic species } \\
\hline Pterigynandrum filiforme Hedw. & & & 2 & 2 & 2 & 1 & & 2 & 3 & 4 & 4 & & & 3 & 2 & 4 & 3 & 4 & 2 & 2 & 2 & 2 & 1 & 4 & 2 & 3 & 2 & 1 & 1 & & & \\
\hline Orthotrichum stramineum Hornsch. ex Brid. & 1 & 1 & 2 & 1 & & 1 & & 1 & 1 & 1 & 2 & 1 & 1 & & 1 & & 1 & & & & & & & & & & & & & & & \\
\hline \multicolumn{33}{|l|}{$\begin{array}{l}\text { Characteristic species of the Ulotion crispae } \\
\text { alliance }\end{array}$} \\
\hline Metzgeria furcata (L.) Dumort. & & & 2 & 3 & 1 & & & & 1 & 1 & 2 & & 2 & & & 1 & & 1 & & 2 & & & & 1 & 2 & & & & & & & \\
\hline Hypnum andoi A.J.E.Sm. & 2 & & & & & & 2 & & & & & & 3 & & 3 & & & 3 & 3 & & & & & & & & & & & & & \\
\hline $\begin{array}{l}\text { Lewinskya striata (Hedw.) F.Lara, Garilleti \& } \\
\text { Goffinet. }\end{array}$ & & & & 1 & 1 & 1 & 1 & 1 & 1 & & & & & 1 & & 1 & & 1 & & & & & & & & & & & & & & \\
\hline $\begin{array}{l}\text { Pulvigera Iyellii (Hook. \& Taylor) } \\
\text { Plášek, Sawicki \& Ochyra. }\end{array}$ & & & & & & & & 3 & 2 & & 1 & & & 2 & & & 2 & & & & & & & & 2 & 2 & & & & & & \\
\hline Frullania tamarisci (L.) Dumort. & & 2 & & & & & & & & & & 1 & & & & & & & 2 & 3 & 3 & & & & & & & & 2 & & & \\
\hline Orthotrichum pallens Bruch ex Brid. & & & & & & & & & & & & & & & & & & & & 1 & & & & & & & & & & & & \\
\hline \multicolumn{33}{|c|}{$\begin{array}{l}\text { Characteristic species of the Orthotrichetalia order and Frullanio dilatatae-Leucodontetea sciuroidis } \\
\text { class }\end{array}$} \\
\hline Frullania dilatata (L.) Dumort. & 2 & & 2 & & 2 & 2 & 1 & 2 & 2 & 2 & 2 & & 2 & 3 & 2 & 2 & 3 & 2 & & & & & 1 & 2 & 2 & 3 & 2 & 2 & & 2 & & 2 \\
\hline Radula complanata (L.) Dumort. & 1 & & 1 & 2 & 1 & 2 & 1 & & & & & 1 & & & 1 & 1 & & 2 & & 1 & & & & & 2 & & & & & 1 & & 1 \\
\hline Radula lindenbergiana Gottsche ex C. Hartm. & & 1 & & & & & & & & & & & & & & & & & & & & & & & & & & & & & & \\
\hline Leucodon sciuroides (Hedw.)Schwägr. & 4 & 4 & 4 & 4 & 4 & 4 & 4 & 4 & 4 & 3 & 3 & 2 & 4 & 4 & 4 & 2 & 4 & & 4 & 3 & 4 & 3 & 4 & 3 & & 4 & 3 & 4 & 4 & 5 & 4 & 4 \\
\hline Homalothecium sericeum (Hedw.) Schimp. & 2 & 2 & & & & & & & & & & 4 & & & & & & & 2 & & & 4 & 2 & & 3 & & & 3 & 4 & 2 & 3 & 3 \\
\hline Zygodon rupestris Schimp. ex Lorentz. & & & & & & & & & & & & & & & & & & & & & & & & & & & & & 1 & & 2 & 1 \\
\hline $\begin{array}{l}\text { Lewinskya affinis (Schrad. ex Brid.) } \\
\text { F.Lara, Garilleti \& Goffinet. }\end{array}$ & & & & & & & & & & & & & & & & & & & & & & & 1 & & 1 & & & & & & 1 & \\
\hline
\end{tabular}


Eurasian Journal of Forest Science - Epiphytic bryophyte vegetation of Beldibi by Alataş et al. 2019

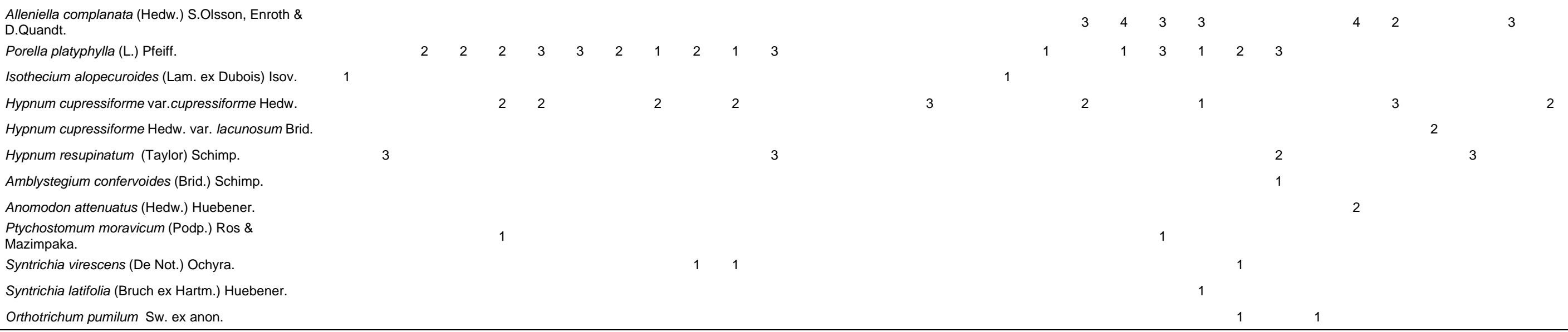


The proportion of obligate epiphyte members within the association is the highest with $48 \%$. Despite that the proportions of cortico-saxicolous (33\%) and indifferent taxa (19\%) are relatively lower within the association (Fig. 3). Therefore, it can be say that the association is epiphytic.

The association was classified into the alliance Ulotion crispae Barkman 1958, the ordo Orthotrichetalia Hadac in Klika \& Hadac 1944 and, the class Frullanio dilatatae-Leucodontetea sciuroidis Mohan 1978, due to it included the diagnostic species of these upper sytaxonomic units (Table 5).

Additionally, the association, recorded for the first time from Turkey by Alataş and Uyar (2017), show floristic and ecologic similarity to previously determined association in the Abant Mountains, due to ecological characteristics and diagnostic species of both associations and of the upper syntaxonomic units are same.

\section{Classification and ordination with multivariate analysis techniques}

Two-Way Indicator Species Analysis (TWINSPAN) that classifies communities according to their floristic similarity, and Detrended Correspondence Analysis (DECORANA), as an ordination technique, were applied to the presence estimates of the recorded taxa in 55 sample plots. TWINSPAN classified epiphytic bryophyte vegetation into three clusters at third hierarchical level (Fig. 4). According to the indicator species clusters were as follows; Orthotrichum stramineum (cluster I), Anomodon viticulosus (cluster II) and, Neckera crispa (cluster III). The results obtained by TWINSPAN indicated that the classification of the communities are appropriate to that of BraunBlanquet's table arrangements.

The Detrended Correspondance Analysis (DCA), an indirect gradient analysis technique, distributed the epiphytic communities on axis 1and axis 2 to three groups (I, II and III) according to the ecological characteristics of the epiphytic habitats (Fig. 5). The DCA ordination agreed well with TWINSPAN clusters. According to this; axis 1 clearly represented that the groups were distributed according to the humidity gradient of epiphytic habitats. The axis 2 was not so clear. But, for axis 2 could be said that the groups were distributed according to the height gradient (from lower base to upper zones) of epiphytic habitats on the phorophytes. Results obtained by DCA ordination showed that the spatial distribution of epiphytic bryophyte communies in the study area were affected by the ecological factors of the habitats. Especially humidity the most important ecological factor in community structures and distribution. 


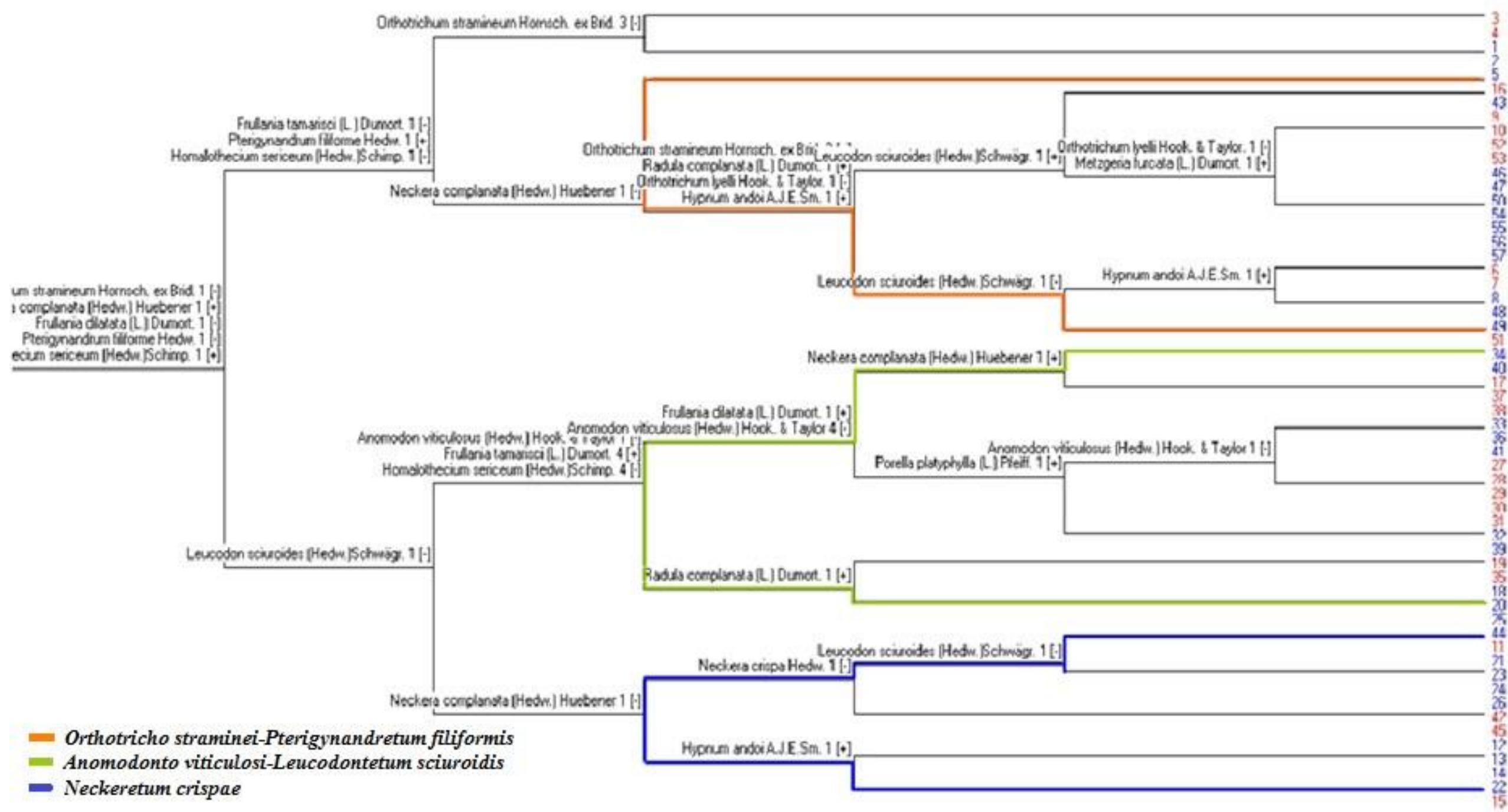

Figure 4. Dendrogram with clusters obtained by TWINSPAN. 


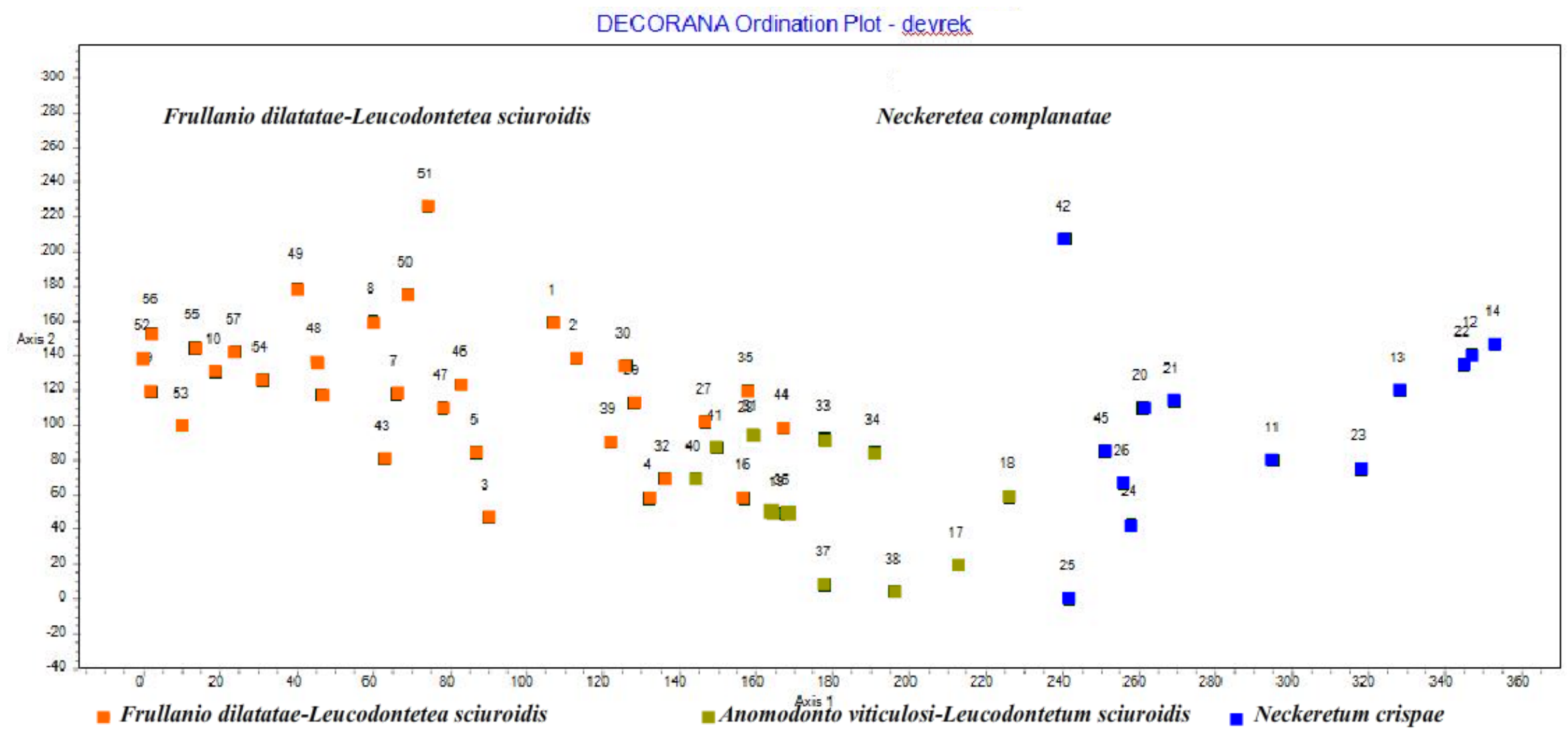

Figure 5.The demonstration of plots on DCA ordination diagram. 


\section{Acknowledgements}

We would like to thank the staff of the Zonguldak Forest District Directorate for their help in the field work.

\section{References}

Akman, Y. (2011). İklim ve Biyoiklim (Biyoiklim metodları ve Türkiye İklimleri). Palme Yayıncılık, Ankara, TR, pp. 1-345.

Alataş, M., Uyar, G. (2017). A New Bryophyte Community and Three New Records for the Epiphytic Bryophyte Vegetation of Turkey. Turk J Bot 41, 308-323.

Alataş, M., Batan, N., Ezer, T., Uyar, G. (2017). The Epiphytic Bryophyte Flora and Vegetation of Boraboy and Destek Forets (Amasya, Turkey). Pakistan J Bot 49 (5), 1779-1786.

Alataş, M. (2018). Checklist of Turkish bryophyte vegetation. Botanica Serbica 42, 173-179.

Alataş, M., Batan, N., Ezer, T. (2019). The epiphytic bryophyte vegetation of Kamilet Valley (Artvin, Turkey). Turk J Bot 43, 551-569.

Anşin, R. (1983). Türkiye’nin Flora Bölgeleri ve Bu Bölgelerde Yayılan Asal Vejetasyon Tipleri. Karadeniz Universitesi Dergisi 6, 2.

Braun Blanquet, J. (1964). Pflanzensoziologie Grundzüge der Vegetationskunde. 3. Aufl. Springer, New York, USA, pp. 1-865.

Barkman, J.J. (1958). Phytosociology and ecology of cryptogamic epiphytes. Van Gorcum, Assen, NL, pp. 1719.

Can Gözcü, M., Uyar, G., Alataş, M., Ezer, T., Ören, M. (2018). Epiphytic bryophyte vegetation of the Samanlı Mountains (Sakarya- Kocaeli-Yalova-Bursa) in Northwest Turkey. Botanica Serbica 42, 157-171.

Casas, C., Brugués, M., Cros, M.R., Sérgio, C., Infante, M. (2009). Handbook of Liverworts and Hornworts of the Iberian Peninsula and the Balearic Islands. Institut d'Estudis Catalans, Barcelona, ES, pp. 1-177.

Cortini Pedrotti, C. (1988). Le associazioni di briofite epifite del Leccio (Quercus ilex) in Umbria. Braun Blanquetia 2, 239-247.

Cortini Pedrotti, C. (2001). Flora dei muschi d'Italia, Sphagnopsida, Andreaopsida, Bryopsida (I parte). Antonio Delfino Editore Medicina-Scienze, Roma, IT, pp. 1-817.

Cortini Pedrotti, C. (2006). Flora dei muschi d'Italia, Bryopsida (II parte). Antonio Delfino Editore MedicinaScienze, Roma, IT, pp. 827-1235.

Ezer, T. (2017). Epiphytic Bryophyte Communities and Succession on Platanus orientalis trees in Kadıncık Valley (Mersin/Turkey). Pakistan J Bot 49 (2), 623-630.

Frey, W., Kürschner, H. (1991). Crossidium laevipilum Ther. Et.Trab. (Pottiaceae, Musci), Ein Eigenstandiges, Morphologisch und Standortökologisch Deutlich Unterscheidbares Taxon Der Saharo-Arabischen Florenregion. Criptogamie Bryol 12, 441-450.

Frey, W., Frahm, J.P., Fischer, E., Lobin, W. (2006). The liverworts, mosses and ferns of Europe. Harley Books, Essex, GB, pp. 1-512.

Goia, I., Schumacker, R. (2004). The study of corticolous bryophytes communities from the Arieşul Mare Basin. Contribuţii Botanice 39, 105-114.

Guerra, J., Cros, M. (2007). Flora Briofítica Ibérica. Vol.1. Universidad de Murcia Sociedad Española de Briología, Murcia, ES, pp. 1-183.

Güvenç, Ş., Öztürk, Ş., Oran, S. (2009). Additions to Lichen Flora of Zonguldak Province. Journal of Biological and Environmental Sciences 3(7), 1-6.

Hedenäs, L. (1992). Flora of Maderian Pleurocarpous Mosses (Isobryales, Hypnobryales, Hookeriales). Bryophytorum Bibliotheca, Stuttgart, DE, pp. 1-165.

Henderson, D.M. (1961). Contribution to the Bryophyte Flora of Turkey IV. Notes Roy. Bot. Gard. Edinburgh 23, 263-278.

Heyn, C.C., Herrnstadt, I. (2004). The Bryophyte Flora of Israel and Adjacent Regions. The Israel Academy of Sciences and Humanities, Jerusalem, IL, pp. 1-719.

Hill, M.O. (1979b) Twinspan-A fortran program for arranging multivariate data in anordered two way table by classification of individual and attributes, Cornell University, Section of Ecology and systematic, Ithaca, NY.

Hill, M.O. (1979a) Decorona-A fortran program for detrended correspondance analysis and reciprocal averaging, Cornell University, Section of Ecology and systematic, Ithaca, NY.

Kürschner, H., Frey, W. (2011). Liverworts, Mosses and Hornworts of Southwest Asia. Beiheft, Stuttgart, DE, pp. 1-239.

Lara, F., Garilleti, R., Goffinet, B., Draper, I., Medina, R., Vigalondo, B., Mazimpaka, V. (2016). Lewinskya, a new genus to accommodate the phaneroporous and monoicous taxa of Orthotrichum (Bryophyta, Orthotrichaceae). Cryptogamie Bryol 37, 361-382.

Marstaller, R. (2006). Syntaxonomischer Konspekt der Moosgesellschaften Europas und angrenzender Gebiete. Haussknechtia Beiheft, Jena, DE, pp. 1-192.

Nyholm, E. (1981). Illustrated Moss Flora of Fennoscandia. Fasc. 1-6. Nordic Bryological Society, Lund, SE, pp. 1-799. 
Paton, J. (1999). The Liverworts Flora of the British Isles. Harley Books, Oxon, GB, pp. 1-626.

Plášek, V., Sawicki, J., Ochyra, R., Szczecińska, M., Kulik, T. (2015). New taxonomical arrangement of the traditionally conceived genera Orthotrichum and Ulota (Orthotrichaceae, Bryophyta). Acta Mus. Siles. Sci. Natur. 64, 169-174.

Smith, A.J.E. (2004). The Moss Flora of Britain and Ireland. Cambridge Univ. Press, Cambridge, GB, pp. 11012.

URL 1. Climate Date. http://en.climate-data.org/location/19438/ (20.05.2015).

Weber, H.E., Moravec, J., Theurillat, J.P. (2000). International Code of Phytosociological Nomenclature. Vegatation Scince 3, 739-768.

Zander, R.H. (1993). Genera of The Pottiaceae: Mosses of Harsh Enviroments. Bullettin of the Buffalo Society of Naturel Sciences, Newyork, USA, pp. 1-378.

Submitted: 18.02.2019 Accepted: 07.10.2019 